\author{
V.P. Kovbasa ${ }^{1}$, A.V. Solomka ${ }^{2}$, A.V. Spirin ${ }^{1 *}$, \\ V.Yu. Kucheruk ${ }^{3}$, D.Zh. Karabekova ${ }^{4}$, A.K. Khassenov ${ }^{4}$ \\ ${ }^{I}$ National Agrarian University, Vinnitsa, Ukraine; \\ ${ }^{2}$ National University of Life and Environmental Sciences of Ukraine, Kiev, Ukraine; \\ ${ }^{3}$ Vinnitsa national technical university, Ukraine; \\ ${ }^{4}$ Karaganda University of the name of academician E.A. Buketov, Kazakhstan \\ (*E-mail: spirinanatoly16@gmail.com)
}

\title{
Theoretical determination of the distribution of forces and the size of the boundaries of the contact in the interaction of the deformable drive wheel with the soil
}

\begin{abstract}
The article presents the results of an analytical determination of the forces distribution along the length of the contact curve of the driving deformable wheel on the deformable supporting surface, and also are defined the boundaries of the contact zone. The case in a flat statement of the problem is considered. The supporting surface and the surface of the deformable wheel are represented as a continuous deformable medium. The shape of the wheel in the contact zone is represented by the circle equation, which in the contact zone is expanded in a Macloran-series. By using conditions at the boundaries of the contact zone, a system of equations is obtained from which the sizes of the contact zone are determined. The solution of these equations allows one to find expressions of the sizes of the contact zone of the deformable wheel with the deformable surface, depending on the mechanical properties of the wheel materials and the supporting surface, from the geometric dimensions of the wheel and from the loads applied to it. In addition, the results of the studies allow us to determine the analytical expression of the coefficient of rolling resistance of a deformable wheel over a deformable surface, depending on their mechanical properties, geometric parameters, and the loads applied to it.

Keywords: deformable wheel, deformable supporting surface, contact zone boundaries, applied loads, forces distribution in the contact zone, absolute deformations, medium mechanical properties, two-dimensional problem.
\end{abstract}

\section{Introduction}

Manufacturing processes in many industries involve the interaction of deformable drive wheels with deformable bearing surfaces. These processes include the movement of transport and technological means and machines during mining, in agricultural, land reclamation, construction, road and other industries. In this case, it is necessary to solve the problem of the interaction of deformable wheels with a supporting surface, which is deformed also. This is necessary to ensure the passability of the machines and provide the necessary tractive effort, the necessary adhesion of the wheels, as well as to ensure the permissible deformation of the supporting surface and for reduce the resistance to movement of the machine, etc. When solving the above problems, questions arise about the size of the contact spot of the deformable wheel and the supporting surface, and the magnitude of their deformations, and the distribution of forces in the contact zone. In this case, it is necessary to take into account the reasons for the occurrence of sliding and skidding of the wheel, as well as the distribution of stresses and deformations on the wheel surface and on the supporting surface in the contact zone itself and at a certain distance from it. It is also necessary to take into account possible violations of the continuity of the structure of the supporting surface (destruction).

By the stresses magnitude and their distributions in the supporting surface, it is possible to judge about the load-bearing capacity of the supporting surface, about change of its mechanical properties and the conditions for the occurrence of slipping of the wheel and its passability. Knowing the deformations magnitudes of the wheel surface and of supporting surface, as well as the applied loads, it is possible to determine the resistance to rolling of the wheel. In such problems, two cases of rolling the deformable wheel along the supporting surface should be distinguished: the rolling of a passive wheel to which no torque is applied, and the rolling of the drive wheel, i.e. wheel to which torque is applied. From the point of view of the mechanics of interaction, the rolling of a passive wheel is a special case of rolling of the drive wheel. Therefore, it is advisable to consider a more general case - the rolling of a drive wheel. 
An analysis of known studies of this problem shows that all the results can be divided into three groups: 1) analytical studies of a fundamental and applied nature; 2) the construction of solutions using well-known models by numerical methods - mainly methods of finite elements (FEM) and finite volumes (DEM); 3) purely experimental research. It should be noted that the first group of studies can give a fairly complete picture of the physical nature of the process and the effect of wheel geometrical parameters on it, the mechanical properties of both the wheel and the supporting surface, and the loads applied to it. The relationship of these values gives the most complete picture of the process and allows you to determine the direction of their influence on the final result of such an interaction.

A significant contribution to the analytical solution of contact interaction problems belongs to A.Yu. Ishlinsky [1, 2], D.I. Zolotarevskaya [3, 4] and others. But an analysis of these works allows us to conclude that not all of these works were taken into account conditions for the application of forces, in particular torque, in addition, the solution to these problems does not give an answer to how the absolute strains are distributed in the vertical and longitudinal directions of the contact zone. In addition, in these solutions there is no clear definition of the boundaries of the contact zones and their dependence on the nature of the application of forces of geometric shapes and the stress-related properties of the contacting bodies.

More modern studies consider numerical solutions of contact problems using the FEM and DEM methods [5-8]. Unfortunately, these works do not give an answer to the question: how do the geometric parameters of the deformable wheel, of the deformable surface, and the magnitudes of the applied loads affect the magnitude of the contact patch. In addition, these results do not have generality, which does not allow us to extend them to more general cases.

It should be noted that the boundaries of the contact patch are used in solving the contact problem in the form of integration limits of potential biharmonic functions that describe solutions of the Laplace systems of equations. These systems are solutions to contact problems in the Papkovich-Neiber form. Therefore, finding the boundaries of the contact of the deformable wheel with the deformable supporting surface is an actual fundamental and applied problem.

The main part of the solving of the contact problem is the analytical determination of the distributed pressures and deformations in the contact zone of the deformable wheel with the supporting surface and the determination of the contact boundaries depending on the applied forces, from the geometric dimensions and shapes of the wheel, as well as the mechanical properties of the wheel and the supporting surface in a flat definition.

This problem definition is suitable for the case of the absence of transverse forces (the condition of linear rolling without taking into account the transverse components of the forces in the contact zone).

\section{Experimental}

To describe the contact interaction of the wheel and the surface on which it moves, it is necessary to solve the following tasks:

- deduce the functions of distributed loads in the contact zone under the action of concentrated forces and moments;

- determine the boundaries of the contact zones of the deformable wheel with the deformable surface.

In general, the procedure for solving a contact problem in an analytical form, for the case of geometric linearity of the equations, that connect stress and strain involves the search for functions that are a solution to elliptic equations.

The main types of such solutions are given in the fundamental literature on mathematical physics [9] and consist in the search for analytical biharmonic potential functions that satisfy the conditions on the surface. These are solutions equations Businesk, Cherruti, P.F. Papkovich and Neuber [10-12].

Taking into account the conditions of the problem statement, it can be assumed that there are no vertical displacements of the coordinate system $x o z$. In this case, one can apply analogs of the solutions of V.M. Aleksandrov, and M.I. Chebakov [13], T.I. Argatov and N.N. Dmitriev [14], as well as V.L. Popov [15], V.P. Kovbasa [16, 17] and others.

These solutions can describe the relationship of the vertical displacements of points of contact surfaces of deformable bodies under vertical and horizontal loading in the form:

$$
v_{p}[x, 0]=M_{p} \int_{a_{1}}^{a}\left(\left(v_{1 p}\left(-F_{\xi}+F_{m \xi}\right)+v 2 p F_{t \xi}\right) \frac{B \mathrm{l}}{\mathrm{l}^{2}+(x+\mathrm{l}-\xi)^{2}}\right) \mathrm{d} \xi
$$




$$
v_{k}[x, 0]=M_{k} \int_{a_{1}}^{a}\left(\left(v_{1 k}\left(F_{\xi}-F_{m \xi}\right)+v_{2 k} F_{t \xi}\right) \frac{B \mathrm{t}}{\mathrm{l}^{2}+(x+\mathrm{l}-\xi)^{2}}\right) \mathrm{d} \xi,
$$

where $v_{p}[x, 0], v_{k}[x, 0]$ - are the displacement (or velocities displacements), depending on the mediums models, in the direction of the vertical coordinate axis of the contact between the support surface and the wheel surface along the length of the contact zone $\left\{a_{1}, a\right\}$ (it should be noted that the arguments in square brackets indicate that the contact surface is considered at $z=0$ for the soil and wheel, respectively (Fig. 1); $F_{t \xi}$ - distributed propulsive pressure in the contact zone; $F_{\zeta}$ - gravity pressure caused by the mass applied to the wheel in the contact zone; $F_{m \xi}$ - distributed pressure from the vertical reaction force, which is due to the rolling resistance moment in the contact zone $\{0, a\} ; M_{p}=\frac{\mathrm{e}^{-\frac{G_{p} t}{\mu_{p}}}\left(-1+\mathrm{e}^{\frac{G_{p} t}{\mu_{p}}}\right)}{6 G_{p}\left(1+\mathrm{v}_{p}\right)}, M_{k}=\frac{\mathrm{e}^{-\frac{G_{k} t}{\mu_{k}}}\left(-1+\mathrm{e}^{\frac{G_{k} t}{\mu_{k}}}\right)}{6 G_{k}\left(1+\mathrm{v}_{k}\right)}$ $v_{1 p}=2\left(-2+v_{p}\right), \quad v_{2 p}=\left(-1+5 v_{p}\right), v_{1 k}=2\left(-2+v_{k}\right), v_{2 k}=\left(-1+5 v_{k}\right)$ - stress-related complexes of wheel and supporting surface properties; $G_{p}, G_{k}, \mu_{p}, \mu_{k}, v_{p}, v_{k}$ - elastic moduli, shear strain viscosity coefficients and lateral expansion coefficients (in the first approximation, Poisson's ratios) of the supporting surface and wheel, respectively.

With prolonged deformation, the exponential functions that enter to $M_{p}, M_{k}$ become to unit and depend only on the elastic moduli and the lateral expansion coefficients; $1, B=\pi / 5 b-$ a coefficient that eliminates the singularity of functions (4) and ensures the fulfillment of conditions at the boundary [16, 17].

These equations (1) can be used to determine the components of absolute deformations, and to determine the components of the strain rates of the wheel and the strain rates of the supporting surface in the zone of their contact.

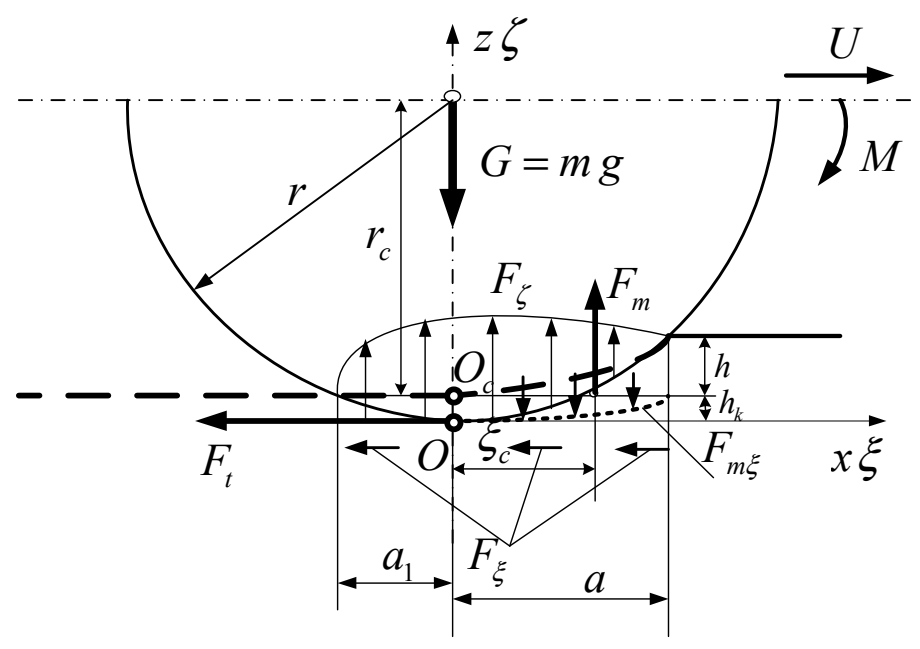

Figure 1. Scheme of interaction of deformable drive wheel with a deformable medium

We can visually represent the nature of the pressures in the contact zone from the scheme of the interaction of the active wheel with the supporting surface (Fig. 1). The fixed coordinate system is denoted as $x O z$. The movable coordinate system in which the deformations of the wheel and the supporting surface are described is represented as $\xi O \zeta$. In this coordinate system, the wheel surface equation is: $\zeta=r-\sqrt{r^{2}-\xi^{2}} ; \xi=r-\sqrt{r^{2}-\zeta^{2}}$. In general, to the wheel a moment $M$ acts, which creates a driving force, a distributed rolling resistance pressure acts and a vertical load $G=m g$.

The rolling resistance forces, on the one hand, are formed in front of the contact zone by a distributed horizontal soil reaction (reaction to a torque component relative to the rotation instantaneous center). The resistance moment to rolling is the product of the integral function of the distribution of resistance force to rolling by the coordinate of the center of its distribution with respect to the coordinates center. On the other 
hand, the resistance moment to rolling is the product of the integral function of the distribution center of the vertical components in front of the contact zone and the coordinate of the rotation instantaneous center. These vertical components arise due to the reaction of the soil to the weight applied to the wheel.

If we take into account the presence of components of distributed pressures, then first of all it is necessary to determine the distribution of pressures in the contact zone. In this case, one should take into account the shape of the contact surface in the vertical-longitudinal plane. For the convenience of further transformations, the transcendental shape of the curved contact surface $\zeta=r-\sqrt{r^{2}-\xi^{2}}$ can be represented in the form of a Maclaurin series at the contact area $a_{1}-a$. Then the shape of the curve will take the form: $\zeta_{n}=\xi^{2} / 2 r$. The coincidence of the real curve and its expansion in a series over the length of the contact section is evidenced by the graphical presentation of these functions and their derivatives along the contact length (Fig. 2).

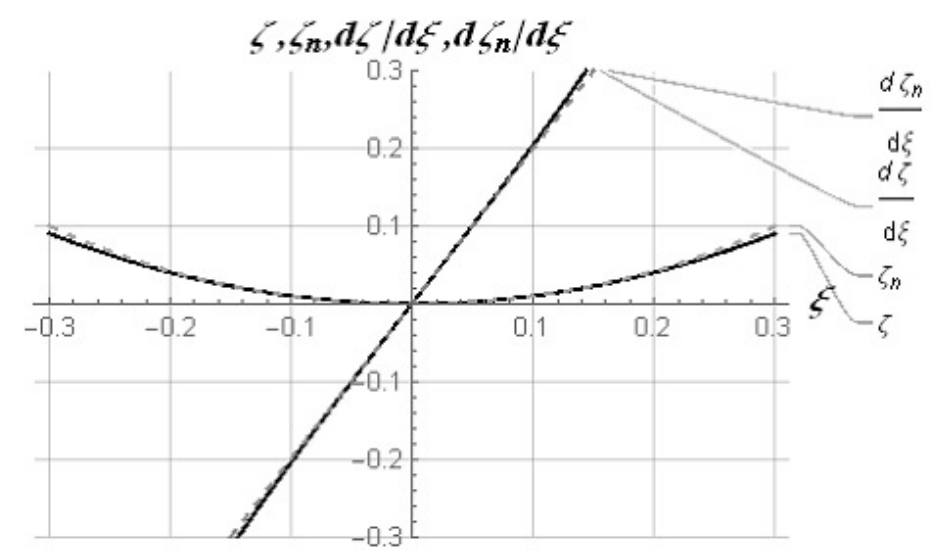

Figure 2. Comparison of the exact analytical expressions of the curve in the contact zone and its expansion into the Maclaurin series

To determine the pressure distribution along the length of the contact surface, one can take into account the properties of a curvilinear integral of the second kind. That is, the pressure distribution along the length of the contact zone $\left\{a_{1} ; a\right\}$ can be represented by the equation:

$$
\frac{d}{d \xi}\left(\int \frac{G}{\left(a-a_{1}\right)} d \xi\right)=\frac{d}{d \xi}\left(\int\left(F_{\varsigma} \sqrt{1+\left(\frac{d}{d \xi}\left(\frac{\xi^{2}}{2 r}\right)\right)^{2}}\right) d \xi\right) .
$$

Hence, the distribution of pressure from the action of gravity per wheel is:

$$
F_{\zeta}=\frac{G}{\left(a-a_{1}\right) \sqrt{1+\frac{\xi^{2}}{r^{2}}} .}
$$

The distribution of the propulsive force created by the torque can be determined based on the above equation:

$$
\frac{d}{d \xi}\left(\int F_{t} \mathrm{~d} \xi\right)=\frac{d}{d \xi}\left(\int \frac{M}{r} \mathrm{~d} \xi\right)=\frac{d}{d \xi}\left(\int F_{t \xi} \sqrt{1+\left(\frac{d}{d \xi}\left(\frac{\xi^{2}}{2 r}\right)\right)^{2}} \mathrm{~d} \xi\right)
$$

From here, the distributed force from the action of the torque is created by tangential tractive effort that distributed over the contact patch:

$$
F_{t \xi}=\frac{M r \sqrt{1+\frac{\xi^{2}}{r^{2}}}}{\left(a-a_{1}\right)\left(r^{2}+\xi^{2}\right)} .
$$

The distribution of the force that creates the rolling resistance moment of the wheel in the contact area $\{0 ; a\}$, is also determined using a curvilinear integral of the second kind: 


$$
\frac{d}{d \xi}\left(\int F_{m} \mathrm{~d} \xi\right)=\frac{d}{d \xi}\left(\int(M /(r / a)) \mathrm{d} \xi\right)=\frac{d}{d \xi}\left(\int\left(-F_{m \xi}(\xi-a)^{2}\right) \mathrm{d} \xi\right),
$$

hence the distributed force due to the moment of rolling resistance will have the form:

$$
F_{m \xi}=-\frac{a M}{r(a-\xi)^{2}} \text {. }
$$

To determine the boundaries of the contact of the wheel with the soil with subsequent integration of these forces distributions, insurmountable difficulties will also arise. In order to prevent the complexity of integration of functions (1), expressions (2), (3), (4) were expanded into Maclaurin series within the length of the contact zone of two bodies:

$$
\begin{gathered}
F_{n}=\frac{g m\left(2 r^{2}-\xi^{2}\right)}{2\left(a-a_{1}\right) r^{2}} ; F_{t n}=\frac{M\left(2 r^{2}-\xi^{2}\right)}{2\left(a-a_{1}\right) r^{3}} ; \\
F_{m n}=-\frac{M\left(a^{2}+2 a \xi+3 \xi^{2}\right)}{a^{3} r},
\end{gathered}
$$

here $F_{n}$ - weight force pressure, which has been expanded to the Maclaurin series; $F_{t n}$ — propulsive force pressure, which has been expanded to the Maclaurin series; $F_{m n}$ - rolling resistance pressure, which has been expanded to the Maclaurin series.

The adequacy of the functions expansions and their originals can be judged by their graphical interpretation (Fig. 3), the analysis of which allows us to conclude that they can be used for further solutions.
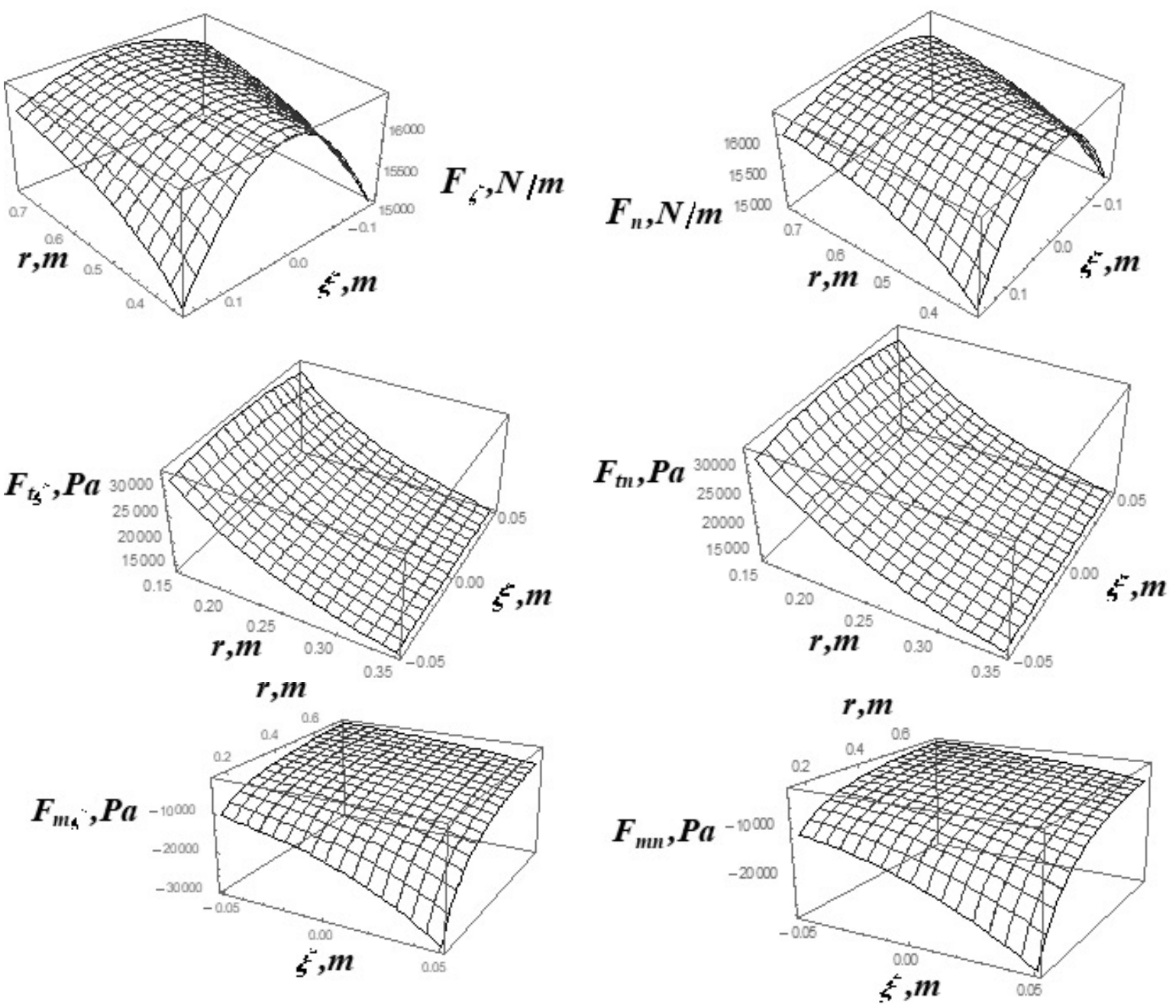

Figure 3. Pressure distribution graphs in the contact zone, plotted both by exact expressions and by their expansion to the Maclaurin series 
Thus, the above functions of pressure distributions of the weight force, propulsive force, and rolling resistance, which has been expanded to the Maclaurin series, make it possible to integrate expressions (1) in a final form. Moreover, the boundaries of these integrals are arguments that designate the front and back boundaries of the contact. From the obtained expressions, the dependences of the boundaries of the contact zone can be determined.

\section{Results and Discussion}

An analysis of the expressions for the distribution of normal pressure in the contact zone (functions (2), (5)) allows us to conclude that this magnitude is directly proportional to the mass applied to the wheel and inversely proportional to the magnitude of the radius of the wheel and the length of the contact zone. A similar conclusion can be made regarding the tangent component of the pressure distribution in the contact zone (functions (3), (5)): this magnitude is also directly proportional to the propulsive force applied to the wheel in the contact zone, and inversely proportional to the length of the contact zone and the radius of the wheel. The distribution of vertical pressure from the action of rolling resistance forces (functions (3), (5)) indicates that this magnitude is also directly proportional to the torque applied to the wheel in the contact zone and inversely proportional to the length of the contact zone and the radius of the wheel.

From this it should be concluded that the determination of the size and boundaries of the contact zone have a decisive role in the study of the contact interaction of a deformable wheel with a deformable surface.

Solving the problem of the contact interaction of two deformable bodies of inconsistent geometric shape in the presence of normal and tangential pressures in the contact zone requires determining the length of the contact zone. In this case, the length of the contact zone should be determined taking into account the magnitudes of the applied loads, of the mechanical properties of the wheel and the supporting surface, as well as the wheel geometric parameters.

Finding the sizes and contact zones can be performed on the basis of solutions of equations (1) for the absolute vertical displacements of the wheel surfaces and the boundary of the supporting surface. In this case, one should consider the solutions of the system of obtained equations of vertical displacements at the contact boundaries.

The boundaries of the contact zone should be determined from the conditions at the edges of the contact boundary. At the rear contact boundary at the point $a_{1}$ the vertical displacement is equal to the deformation of the wheel surface $a_{1}^{2} / 2 r$. The second boundary condition is determined by the total displacement from the deformations of the wheel surface and the bearing surface at the beginning of the front contact boundary. This offset is 0 . Based on these boundary conditions, a system of equations was compiled:

$$
\begin{gathered}
\left.v_{k}\right|_{\left\{a_{1}, a \rightarrow 0\right\}}=M_{k} \int_{a_{1}}^{0}\left(\left(v_{1 k}\left(F_{\xi}-F_{m \xi}\right)+v_{2 k} F_{t \xi}\right) \frac{B \mathrm{l}}{\mathrm{l}^{2}+(x+\mathrm{l}-\xi)^{2}} \mathrm{~d} \xi-\frac{a_{1}^{2}}{2 r} ;\right. \\
\left.\left(v_{k}-v_{p}\right)\right|_{\left\{a, a_{1} \rightarrow 0\right\}}=\int_{0}^{a}\left(\left(\begin{array}{l}
M_{k}\left(\left(v_{1 k}\left(F_{\xi}-F_{m \xi}\right)+v_{2 k} F_{t \xi}\right)-\right. \\
-M_{p}\left(\left(v_{1 k}\left(F_{\xi}-F_{m \xi}\right)+v_{2 k} F_{t \xi}\right)\right.
\end{array}\right) \frac{B \mathrm{r}}{\mathrm{l}^{2}+(x+\mathrm{l}-\xi)^{2}}\right) \mathrm{d} \xi .
\end{gathered}
$$

The integration of these expressions is carried out taking into account that $x=\xi$.

The results of integration of expressions (6) include transcendental components in the form: $\operatorname{ArcTan}[(a+\mathrm{l}) / \mathrm{l}], \ln \left[2 \mathrm{\imath}^{2}\right], \ln \left[\mathrm{t}^{2}+(a+\mathrm{l})^{2}\right]$. Given the fact that $\ln [f \rightarrow 0] \rightarrow(\approx 3 /(2 \pi))$, and $\operatorname{ArcTan}\left[(a+\mathfrak{l}) /\left.\mathfrak{l}\right|_{\{a \triangleright 0.01, \imath \rightarrow 0\}} \rightarrow \frac{\pi}{2}\right.$, then the expressions can be reduced to a form convenient for solving. In the final form, the solutions of expressions (6) with respect to the values that determine the front and rear contact boundaries (taking into account the signs of the magnitudes of the front and rear boundaries of the contact) have the form:

$$
a_{1}=-\frac{\sqrt{6} \sqrt{g M_{k} m v_{1 k}+\frac{M_{k} M v_{2 k}}{r}}}{\sqrt{\frac{3 r^{2}+g M_{k} m r v_{1 k}+M_{k} M v_{2 k}}{r^{3}}}} ;
$$




$$
a=\frac{\sqrt{2} \sqrt{6 M_{k} M r^{2} v_{1 k}+g M_{k} m r^{3} v_{1 k}+6 M M_{p} r^{2} v_{1 p}+g m M_{p} r^{3} v_{1 p}+M_{k} M r^{2} v_{2 k}-M M_{p} r^{2} v_{2 p}}}{\sqrt{g M_{k} m r v_{1 k}+g m M_{p} r v_{1 p}+M_{k} M v_{2 k}-M M_{p} v_{2 p}}} .
$$

To simplify the analysis of expressions (7), their graphical interpretations are given. Analysis of the graphs (Fig. 4) indicates that the mass, which is given to the wheel, as well as the deformative properties of the wheel surface and the supporting surface, have a significant effect on the size of the rear part of the contact zone.
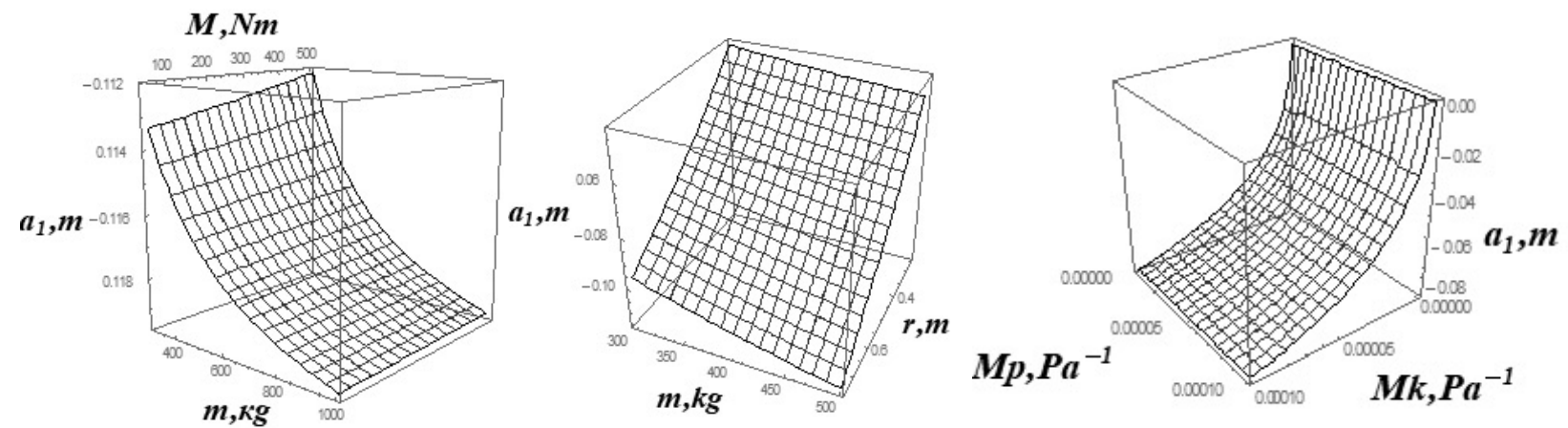

Figure 4. The plots of the dependence of the front contact zone magnitude on the wheel stress-related properties, on the mass applied to the wheel, on the the torque and wheel radius

The size of the front boundary of the contact zone also depends from the mass that applied to the wheel, as well as the deformative properties of the wheel surface and the supporting surface.

The sum magnitude of the front and back of the contact zone indicates a significant influence of the propulsive force, which is created by tangential pressure. At the same time, the mass vertical component has a smaller effect (Fig. 5-6).

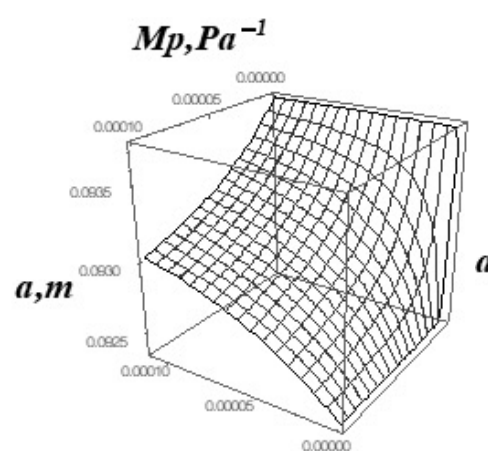

$\boldsymbol{M k}, \mathrm{Pa}^{-1}$
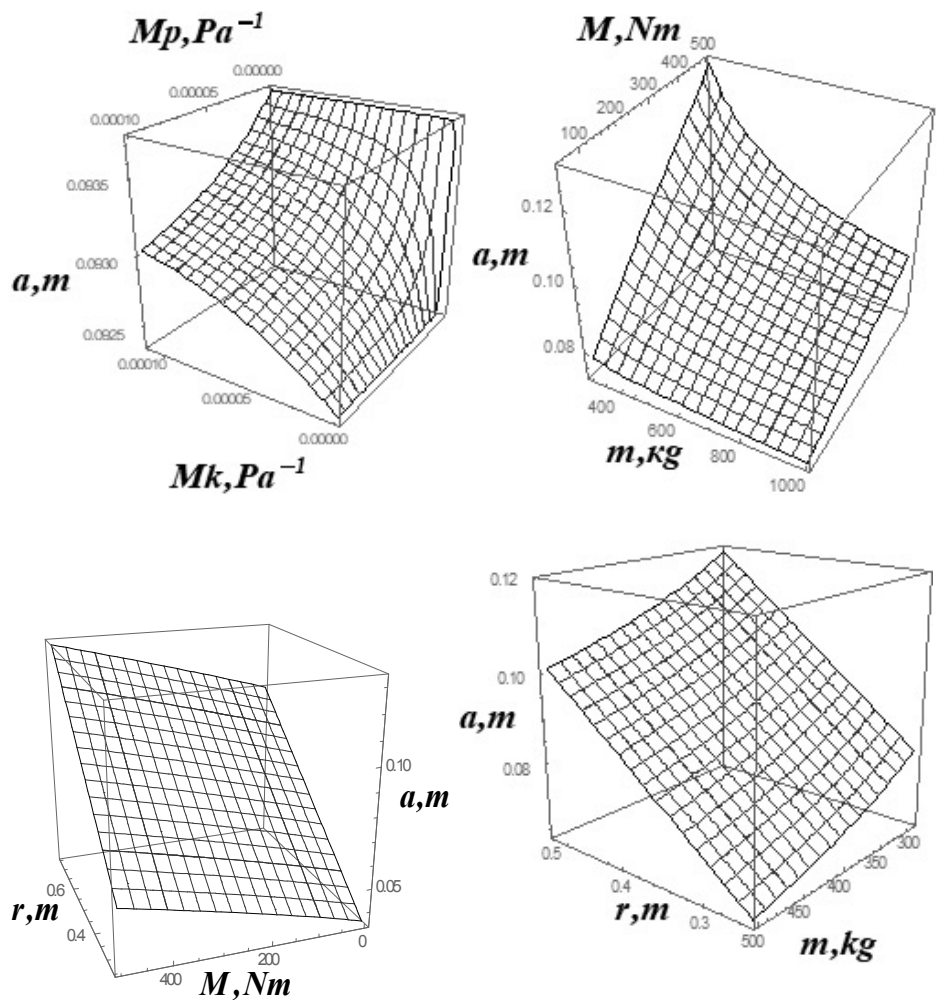

Figure 5. The plots of the dependence of the back contact zone magnitude on the wheel stress-related properties, on the mass applied to the wheel, on the the torque and wheel radius 


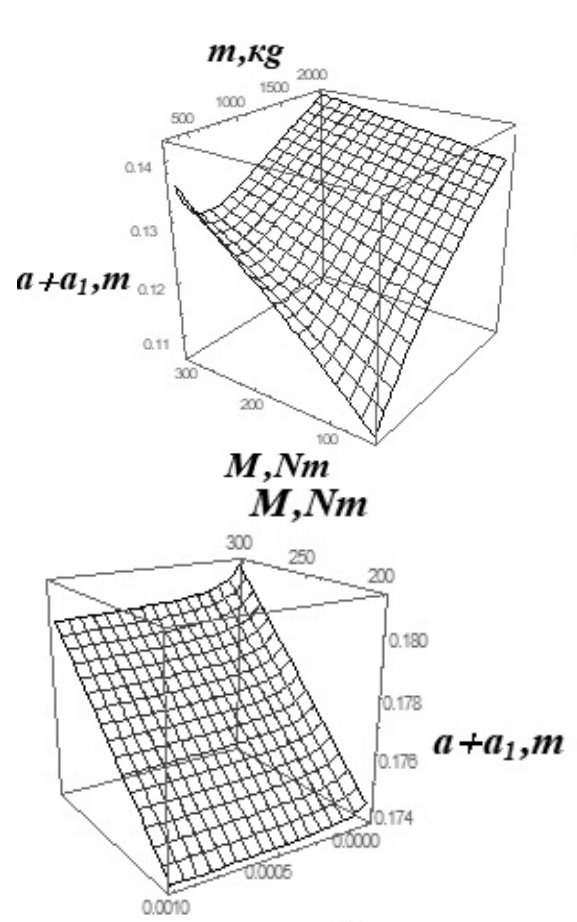

$\mathrm{Mp}, \mathrm{Pa}^{-1}$
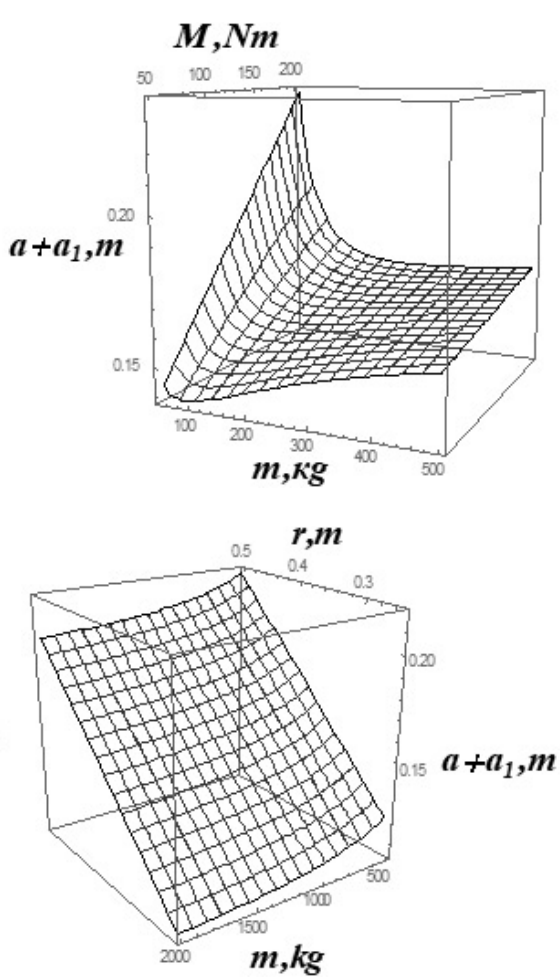

Figure 6. The plots of the dependence of the total magnitude of the contact zone on the wheel stress-related properties, on the mass applied to the wheel, on the the torque and wheel radius

Thus, the conducted studies indicate that the wheel stress-related properties the greatest influence on the size of the contact zone, in contrast to the soil stress-related properties. This may be due to less curvature of the wheel surface.

Analysis of the dependences magnitudes of front $a$ and back $a_{1}$ contact zone of a deformable wheel with a deformable support surface allows us to draw the following conclusions:

- the size of the back boundary of the contact zone $a_{1}$ significantly depends on the deformative properties of the wheel surface $M_{k}$. The deformative properties of the supporting surface $M_{p}$ do not significantly affect this magnitude;

- an increase in pressure from the propulsive force, which is created by the torque $M$, leads to an increase in both the front and back boundaries of the contact zone;

- an increase in the wheel geometric size $r$ increases the size of the back and front parts of the contact zone;

- an increase of the deformative properties of the supporting surface $M_{p}$ entails an increase of the front part of the contact zone;

- an increase in the mass applied to the wheel leads to an increase in the total length of the contact zone $\left(\left|a_{1}\right|+|a|\right)$.

\section{Conclusions}

The carried out theoretical studies made it possible to obtain analytical dependences of the influence of the wheel geometric parameters, of the mechanical properties of the supporting surface and the wheel, as well as of the dynamic loads applied to it, on the dimensions and magnitudes of the boundaries of the contact zone between the deformable wheel and the deformable support surface.

The analytical functions of the magnitudes of contact zone boundaries of the deformable wheel with the deformable supporting surface are the limits of integration of biharmonic potential functions in the Papkovich-Neiber equations for solving this contact problem.

The obtained analytical functions can be used in the design of wheeled propulsions of various technological machines and vehicles, as well as road-building equipment. 
In addition, the functional dependencies of the relationship between the dimensions of the contact zone with the parameters and loading modes of the wheel propulsion, which are presented in the work, are the initial ones for the deepening analytical studies of the contact interaction of deformable bodies of inconsistent geometric shape.

\title{
References
}

1 Ишлинский А.Ю. О качении жестких и пневматических колес по деформируемому грунту. Прикладные задачи механики. Кн. 1 / А.Ю. Ишлинский. - М.: Наука, 1986. - С. 293-314.

2 Ишлинский А.Ю. Математическая теория пластичности / А.Ю. Ишлинский, Д.Д. Ивлев. - М.: Физматлит, 2003. $704 \mathrm{c}$.

3 Золотаревская Д.И. Взаимосвязь различных математических моделей деформирования почвы / Д.И. Золотаревская // Механизация и электрификация сельского хозяйства. — 1983. — № 5. - С. 10-16.

4 Золотаревская Д.И. Основы теории и методы расчета уплотняющего воздействия на почву колесных движителей мобильной сельскохозяйственной техники: дис. ... д-ра техн. наук: 05.20.01 — «Технологии и средства механизации сельского хозяйства» / Д.И. Золотаревская. - М., 1997. - 432 с.

5 Junlong Guoa. Linear normal stress under a wheel in skid for wheeled mobile robots running on sandy terrain / Junlong Guoa, Haibo Gaoa, Liang Ding, Tianyou Guob, Zongquan Deng // Journal of Terramechanics. — 2017. — Vol. 70. — P. 49-57.

6 Wanshen Xiao. Design of manned lunar rover wheels and improvement in soil mechanics formulas for elastic wheels in consideration of deformation / Wanshen Xiao, Yan Zhang // Journal of Terramechanics, — 2016. — Vol. 65. — P. 61-71.

7 Wang Yang. Prediction for Tire-Pavement Contact Stress under Steady-State Conditions based on 3D Finite Element Method / Wang Yang, Sun Tiecheng, Lu Yongjie, Si Chundi // Journal of Engineering Science and Technology. — 2016. — Review 9(4). P. 17-25.

8 Guthrie A.G. 3D contact patch measurement inside rolling tyres / A. Glenn Guthrie, Theunis R. Botha, P. Schalk Els // Journal of Terramechanics. - 2017. - Vol. 69. - P. 13-21.

9 Полянин А.Д. Справочник по линейным уравнениям математической физики / А.Д. Полянин. - М: Физматлит, 2001. - $576 \mathrm{c}$.

10 Новацкий В. Теория упругости / В. Новацкий. - М.: Мир, 1975. - 872 с.

11 Папкович П.Ф. Теория упругости / П.Ф. Папкович. — Л.; М.: Оборонпром, 1939. — 639 с.

12 Партон В.З. Механика упругопластического разрушения / В.З. Партон, Е.М. Морозов. - М.: Наука, 1985. — 504 с.

13 Александров В.М. Введение в механику контактных взаимодействий / В.М. Александров, М.И. Чебаков. - М.; Ростов н/Д., 2007. - 114 с.

14 Аргатов И.И. Основы теории упругого дискретного контакта / И.И. Аргатов, Н.Н. Дмитриев. - СПб.: Политехника, 2003. - $233 \mathrm{c}$

15 Попов В.Л. Механика контактного взаимодействия и физика трения / В.Л. Попов. - М.: Физматлит, 2013. - 352 с.

16 Ковбаса В.П. Механіко-технологічні основи взаємодії робочих органів 3 грунтом / В.П. Ковбаса. — Киев; Нежин, 2016. $-298 \mathrm{c}$.

17 Гуцол О.П. До визначення фізичних рівнянь пружнов язко-пластичного середовища 3 умовою руйнування за модифікованим критерієм Кулона-Мора / О.П. Гуцол, В.П. Ковбаса, В.П. Курка // Праці ТДАТУ. — Мелитополь, 2011. Вып. 11, Т. 2. - С. 161-174.

В.П. Ковбаса, А.В. Соломка, А.В. Спирин, В.Ю. Кучерук, Д.Ж. Карабекова, А.К. Хасенов

\section{Деформацияланатын жетек доңғалағының топырақпен әрекеттесуі кезінде күштердің таралуы мен байланыс шекараларының мөлшерін теориялық анықтау}

\begin{abstract}
Мақалада деформацияланатын тірек бетіндегі деформацияланатын жетек доңғалағының байланыс қисығының ұзындығы бойынша күштердің таралуын аналитикалық анықтау нәтижелері келтірілген және оның байланыс аймағының шекаралары анықталған. Мәселенің тегіс тұжырымындағы жағдай қарастырылған. Деформацияланатын доңғалақтың тірек беті мен беті серпімді модульдермен және Пуассон коэффициенттерімен сипатталатын үздіксіз деформацияланатын орта ретінде ұсынылған. Доңғалақ оған берілген салмақ күшімен және байланыс аймағында қозғалмалы күш тудыратын моментпен жүктеледі. Мұндай өндіріс жалпы болып табылады және пассивті доңғалақтың жанасуы үшін қолданылуы мүмкін. Байланыс аймағындағы доңғалақтың пішіні шеңбер теңдеуімен ұсынылған, ол байланыс аймағында Маклорен қатарына бөлінеді, бұл шешімнің нәтижесіне айтарлықтай әсер етпейді. Контакт аймағының шекарасындағы шарттарды қолдана отырып, теңдеулер жүйесі алынған, оның көмегімен контакт аймағы өлшемдерінің шамалары анықталған. Бұл теңдеулер жүйесін шешу
\end{abstract}


доңғалақтың материалдары мен тірек бетінің Пуассонының серпімділік модульдері мен коэффициенттеріне, оған қоса берілген доңғалақ пен жүктемелердің геометриялық өлшемдеріне байланысты деформацияланатын доңғалақтың деформацияланатын бетімен байланыс аймағының өлшемдерін көрсетті. Зерттеу нәтижелері бойынша доңғалақ беті мен тірек бетінің абсолютті және салыстырмалы деформацияларын, байланыс аймағынан тыс контактілі денелердегі кернеулердің таралуын анықтауға негіз болып табылады, сонымен қатар деформацияланатын доңғалақтың деформацияланатын бетке айналу кедергісі коэффициентінің аналитикалық көрінісін олардың механикалық қасиеттеріне, геометриялық параметрлеріне және қолданылатын жүктемелеріне байланысты анықтауға мүмкіндік береді.

Кілm сөздер: деформацияланатын доңғалақ, деформацияланатын тірек беті, байланыс аймағының шекаралары, қолданылатын жүктемелер, байланыс аймағында қысымның таралуы, абсолютті деформациялар.

\author{
В.П. Ковбаса, А.В. Соломка, А.В. Спирин, \\ В.Ю. Кучерук, Д.Ж. Карабекова, А.К. Хасенов
}

\title{
Теоретическое определение распределения сил и размера границ контакта при взаимодействии деформируемого приводного колеса с почвой
}

\begin{abstract}
В статье представлены результаты аналитического определения распределения сил по длине кривой контакта приводного деформируемого колеса на деформируемой опорной поверхности и определены границы зоны его контакта. Рассмотрен случай в плоской постановке задачи. Опорная поверхность и поверхность деформируемого колеса даны как сплошная деформируемая среда, которая характеризуется модулями упругости и коэффициентами Пуассона. Колесо нагружено силой веса, приведенной к нему, и крутящим моментом, который создает в зоне контакта движущую силу. Такая постановка является общей и может быть применена также для контакта пассивного колеса. Форма колеса в зоне контакта представлена уравнением окружности, которое разложено в ряд Маклорана в зоне контакта, что не оказывает существенного влияния на результат решения. С использованием условий на границе зоны контакта получена система уравнений, из которой определены величины размеров зоны контакта. Решение этой системы уравнений дало выражение размеров зоны контакта деформируемого колеса с деформируемой поверхностью в зависимости от модулей упругости и коэффициентов Пуассона материалов колеса и опорной поверхности, геометрических размеров колеса и нагрузок, приложенных к нему. Результаты проведенных исследований являются основой для определения абсолютных и относительных деформаций поверхности колеса и опорной поверхности, распределения напряжений в контактирующих телах за пределами зоны контакта, а также позволяют определить аналитическое выражение коэффициента сопротивления перекатывания деформируемого колеса по деформируемой поверхности в зависимости от их механических свойств, геометрических параметров и приложенных нагрузок.
\end{abstract}

Ключевые слова: деформируемое колесо, деформируемая опорная поверхность, границы зоны контакта, приложенные нагрузки, распределение давления в зоне контакта, абсолютные деформации.

\section{References}

1 Ishlinskiy, A.Yu. (1986). O kachenii zhestkikh i pnevmaticheskikh koles po deformiruemomu hruntu. Prikladnye zadachi mekhaniki. Kniha 1 [About rolling hard and pneumatic wheels on deformable soil. Applied problems of mechanics. Book 1]. Moscow: Nauka [in Russian].

2 Ishlinskiy, A. Yu., \& Ivlev, D.D. (2003). Matematicheskaia teoriia plastichnosti [Mathematical Theory of Plasticity]. Moscow: Fizmatlit [in Russian].

3 Zolotarevskaya, D.I. (1983). Vzaimosviaz razlichnykh matematicheskikh modelei deformirovaniia pochvy [The relationship of various mathematical models of soil deformation]. Mekhanizatsiia i elektrifikatsiia selskoho khoziaistva - Mechanization and electrification of agriculture, 5, 10-16 [in Russian].

4 Zolotarevskaya, D.I. (1997). Osnovy teorii i metody rascheta uplotniaiushcheho vozdeistviia na pochvu kolesnykh dvizhitelei mobilnoi selskokhoziaistvennoi tekhniki [Fundamentals of the theory and methods of calculating the sealing effect on the soil of wheeled movers of mobile agricultural machinery]. Doctor's thesis. Moscow [in Russian].

5 Junlong Guoa, Haibo Gaoa, Liang Ding, Tianyou Guob, \& Zongquan Deng (2017). Linear normal stress under a wheel in skid for wheeled mobile robots running on sandy terrain. Journal of Terramechanics, 70(4), 49-57.

6 Wanshen Xiao, \& Yan Zhang (2016). Design of manned lunar rover wheels and improvement in soil mechanics formulas for elastic wheels in consideration of deformation. Journal of Terramechanics, 65(6), 61-71.

7 Wang Yang, Sun Tiecheng, Lu Yongjie, \& Si Chundi (2016). Prediction for Tire-Pavement Contact Stress under SteadyState Conditions based on 3D Finite Element Method. Journal of Engineering Science and Technology, 9(4), 17-25. 
8 Guthrie, A.G., Botha, T.R., \& Els, P.S. (2017). 3D contact patch measurement inside rolling tyres. Journal of Terramechanics, 69(2), 13-21.

9 Polyanin, A.D. (2001). Spravochnik po lineinym uravneniiam matematicheskoi fiziki [Handbook of linear equations of mathematical physics]. Moscow: Fizmatlit [in Russian].

10 Novatskiy, V. (1975). Teoriia upruhosti [Elasticity theory]. Moscow: Mir [in Russian].

11 Papkovich, P.F. (1939). Teoriia upruhosti [Elasticity theory]. Leningrad; Moscow: Oboronprom [in Russian].

12 Parton, V.Z., \& Morozov, E.M. (1985). Mekhanika upruhoplasticheskoho razrusheniia [Mechanics of Elastoplastic Destruction]. Moscow: Nauka [in Russian].

13 Aleksandrov, V.M., \& Chebakov, M.I. (2007). Vvedenie v mekhaniku kontaktnykh vzaimodeistvii [Introduction to the Mechanics of Contact Interactions]. Moscow [in Russian].

14 Argatov, I.I., \& Dmitriev, N.N. (2003). Osnovy teorii upruhoho diskretnoho kontakta [Fundamentals of the theory of elastic discrete contact]. Saint Petersburg: Politekhnika [in Russian].

15 Popov, V.L. (2013). Mekhanika kontaktnoho vzaimodeistviia i fizika treniia [Contact mechanics and physics of friction]. Moscow: Fizmatlit [in Russian].

16 Kovbasa, V.P. (2016). Mekhaniko-tekhnolohichni osnovi vzayemodiyi robochih orhaniv z hruntom [Mechanical and technological bases of interaction of tools with soil]. Kyiv; Nezhyn [in Ukrainian].

17 Gucol, O.P., Kovbasa, V.P., \& Kurka V.P. (2011). Do viznachennia fizichnih rivnyan pruzhnov`yazko-plastichnoho seredovischa z umovoyu ruynuvannia za modifikovanim kriteriem Kulona-Mora [On the determination of the physical equations of an elastic-viscous-plastic medium with the condition of destruction by the modified Coulomb-Mohr criterion] Praci Tavriiskoho derzhavnoho ahrotehnolohichnoho universitetu - Proceedings of the Tavria State Agrotechnological University, 11(2), 161-174 [in Ukrainian]. 